\title{
Liver Abscess
}

National Cancer Institute

\section{Source}

National Cancer Institute. Liver Abscess. NCI Thesaurus. Code C99089.

A bacterial, parasitic, or fungal abscess that develops in the liver. It is usually the result of an abdominal infection, trauma, or surgery in the right upper quadrant. Signs and symptoms include abdominal pain, nausea, vomiting, and fever. 